\title{
IMPLEMENTASI METODE UMMI UNTUK MENINGKATKAN KUALITAS MEMBACA AL-QURAN di SDIT IHSANUL AMAL ALABIO
}

\author{
Ahmad Rifa'I \\ Dosen, STIQ Amuntai, Kalimantan Selatan, Indonesia
}

\begin{abstract}
Abstrak
Pendahuluan : Penelitian ini bertujuan untuk menganalisis, memahami, dan mendeskripsikan tentang: Metode Ummi yang dikembangkan di SDIT Ihsanul Amal : (1) Implementasi metode Ummi di SDIT Ihsanul Amal Alabio, (2) Kualitas bacaan al-Quran setelah diterapkan metode Ummi.

Metode : Penelitian ini menggunakan pendekatan kualitatif dengan rancangan studi kasus (case studies). Pengumpulan data dilakukan dengan teknik wawancara, observasi partisipatif, dan dokumentasi. Teknis analisis data meliputi reduksi data, penyajian data, dan kesimpulan, pengecekan keabsahan temuan dilakukan dengan cara keikutsertaan peneliti; teknik triangulasi dengan menggunakan berbagai sumber, teori, dan metode; dan ketekunan pengamatan. Informan penelitian yaitu Kepala Sekolah, Waka Bidang Kurikulum, siswa, dan Kordinator Ummi.

Hasil : (1) Implementasi metode Ummi dalam meningkatkan kualitas membaca al-Quran yaitu Pembelajaran al-Qur'an di SDIT Ihsanul Amal 8 JP/minggu, guru yang mengajar mendapatkan sertifikasi dari Ummi Foundation, guru-guru yang mengajar di SDIT ini juga kebanyakan hafizh-hafizah al-Quran, evaluasi pembelajaran meliputi evaluasi harian, mingguan, bulanan dan semester; (2) Kualitas membaca al-Quran setelah diterapkan metode Ummi menghasilkan bacaan al-Quran yang baik dan sesuai dengan hukum-hukum tajwid yang berlaku.

Keywords : Implementasi, Metode Ummi, SDIT Ihsanul Amal.
\end{abstract}

\section{A. Pendahuluan}

Allah telah banyak berbicara mengenai makhluk ciptaan-Nya dalam al-Qur'an. Allah Maha Tahu tentang keadaan dan seluk-beluk alam semesta, karena Dialah yang menciptakannya. Dialah yang Maha Tahu maksud ayat-ayat al-Qur'an, karena dialah yang memfirmankannya. Alam semesta adalah ayatayat Kauniyah-Nya, sedangkan al-Qur'an adalah ayat-ayat Qauliyah-Nya, 
Ahmad Rifa'i: Implementasi Metode UMMI Untuk Meningkatkat Kualitas Membaca al-Quran di SDIT Ihsanul Amal Alabio

karena itu kandungan ayat-ayat al-Qur'an menyerupai alam semesta (ayat-ayat kauniyah). ${ }^{1}$

Pembelajaran al-Qur'an yang optimal akan melahirkan generasi Qur'ani yang mampu memakmurkan bumi dengan al-Qur'an dan menyelamatkan peradaban dunia di masa mendatang. Syarat mutlak untuk memunculkan generasi Qur'ani adalah adanya pemahaman terhadap al-Qur'an yang diawali dengan mampu membaca al-Qur'an dengan baik dan benar sesuai dengan kaidah yang telah ditentukan.

Mengingat pentingnya pembelajaran al-Qur'an, Rasulullah saw. menganjurkan pembelajaran membaca Al-Qur'an dimulai sejak masa kanakkanak karena pada masa itu terkandung potensi belajar yang sangat kuat dan besar. Anak akan sangat peka menangkap sesuatu yang diperintahkan dan diajarkan sehingga mudah menerima pelajaran-pelajaran yang diberikan. Namun masalahnya, al-Qur'an disampaikan dalam bahasa Arab dan tidak semua umat muslim di Indonesia menguasai bahasa tersebut. Belajar membaca al-Qur'an artinya belajar mengucapkan lambang-lambang bunyi (huruf) tertulis. Walaupun kegiatan ini cukup sederhana, tetapi bagi siswa pemula merupakan kegiatan yang cukup kompleks, karena harus melibatkan berbagai hal, yaitu penglihatan, pendengaran, pengucapan disamping akal pikiran. Kedua hal terakhir ini bekerja secara mekanik dan simultan untuk melahirkan perilaku membaca. Ditambah lagi materi yang dibaca adalah rangkaian kata-kata Arab yang banyak berbeda sistem bunyi dan penulisannya dengan yang mereka kenal dalam bahasa ibu dan bahasa Indonesia. ${ }^{2}$

Apalagi pemandangan yang cukup memprihatinkan adalah akhir-akhir ini dirasakan kecintaan membaca al-Qur'an di kalangan umat Islam sendiri agak semakin menurun. Budaya membaca al-Qur'an di rumah-rumah setelah shalat hlm 16.

${ }^{1}$ Hakim Muda Harahap, Rahasia Al-Quran, (Depok : Darul Hikmah, 2007),

${ }^{2}$ Depag RI, Metode-metode Membaca Al-Qur'an di Sekolah Umum, (Jakarta: Dirjen Pembinaan Kelembagaan Agama Islam, 1997), hlm. 24.

Jurnal Ilmiah AL-MADRASAH, Vol. 2, No. 2, Januari-Juni 2018 
Ahmad Rifa'i: Implementasi Metode UMMI Untuk Meningkatkat Kualitas Membaca al-Quran di SDIT Ihsanul Amal Alabio

fardhu sudah jarang didengarkan. Membaca al-Qur'an telah digantikan dengan bacaan-bacaan atau media-media informasi lain seperti:koran atau surat kabar, majalah, televisi dan lain-lain, padahal mereka tahu membaca al-Qur'an merupakan ibadah yang memperoleh pahala dari Allah SWT. Jika umat Islam sudah merasa tidak penting untuk membaca al-Qur'an,maka siapakah yang akan mau membaca al-Qur'an kalau bukan orang Islam itu sendiri. ${ }^{3}$

Maka begitu pentingnya pendidikan agama, Di Indonesia pendidikan Agama adalah bagian integral dari pendidikan nasional sebagai satu kesatuan. Dalam Undang-Undang RI No. 20 tahun 2003 dijelaskan bahwa :

"Pendidikan nasional berfungsi mengembangkan kemampuan dan membentuk watak serta peradaban bangsa yang bermartabat dalam rangka mencerdaskan kehidupan bangsa, bertujuan untuk berkembangnya potensi peserta didik agar menjadi manusia yang beriman dan bertakwa kepada Tuhan yang Maha Esa, berakhlak mulia, sehat, berilmu, cakap, kreatif, mandiri dan menjadi warga Negara yang demokratis serta bertanggung jawab."4

Pendidikan merupakan hal penting bagi kemajuan dan peradaban umat manusia. Pendidikan bagi manusia adalah merupakan sistem dan cara peningkatan kualitas hidup dalam segala bidang sepanjang sejarah hidup manusia dimuka bumi ini. Pendidikan merupakan proses pendewasaan untuk menuju manusia sempurna, oleh karenanya setiap orang wajib belajar dan menuntut ilmu selama hayat masih dikandung badan. Manusia akan maju dan menjadi manusia sempurna sebagaimana yang dianjurkan agama apabila dia mampu memfungsikan akalnya seoptimal mungkin. Arifin mengatakan dalam bukunya, Kapita Selekta Pendidikan Nasional;

" Pendidikan bagi manusia adalah merupakan sistem dan cara peningkatan kualitas hidup dalam segala bidang, sehingga sepanjang sejarah hidup manusia dimuka bumi ini, hampir tidak ada manusia yang tidak menggunakan pendidikan sebagai

\footnotetext{
${ }^{3}$ Abu Yahya As-Syilasyabi, Cara Mudah Membaca Al-Qur'an Sesuai Kaidah Tajwid, (Yogyakarta: Daar Ibn Hazm, 2007), hlm. 13.

${ }^{4}$ Undang-undang Republik Indonesia No. 22 Tahun 2003 tentang Sistem Pendidiakan Nasional, BAB II pasal 3 tentang Dasar, fungsi dan tujuan.
}

Jurnal Ilmiah AL-MADRASAH, Vol. 2, No. 2, Januari-Juni 2018 
Ahmad Rifa'i: Implementasi Metode UMMI Untuk Meningkatkat Kualitas Membaca al-Quran di SDIT Ihsanul Amal Alabio

alat pembudayaan dan peningkatan kualitasnya, sehingga dalam kelompok masyarakat primitifpun". 5

Pendidikan Islam sebagai alat pembudayaan, memiliki watak lentur terhadap perkembangan cita-cita hidup manusia sepanjang zaman. Namun watak tersebut tetap berpedoman kepada prinsip nilai Islam. Pendidikan Islam mampu mengakomodasi tuntutan hidup manusia dari masa kemasa termasuk bidang ilmu tehnologi dengan sikap mengarahkan dan mengendalikan tuntutan hidup tersebut, dengan nilai fundamental yang bersumber pada iman dan taqwa kepada Allah Swt. Ilmu dan taqwa ini merupakan rujukan dan transparansi tingkah laku manusia yang terpancar dengan getaran hati nurani manusia yang memiliki jiwa kemanusiaan. ${ }^{6}$

Untuk mengoptimalisasikan akal, maka perlu dilakukan melalui pendidikan yang tidak memisahkan antara ilmu pengetahuan teknologi dan ilmu agama. Keduanya harus berjalan selaras secara integral, tidak dipisahkan antara yang satu dengan yang lainnya, karena Islam sangat menjunjung tinggi nilai pendidikan. Hal ini berarti bahwa manusia pada dasarnya adalah makhluk yang dapat dididik dan harus dididik. Dengan adanya pendidikan, keberadaan manusia sebagai khalifah Allah yang diberi tanggung jawab untuk memelihara alam beserta isinya, ini dapat dilaksanakan sesuai dengan aturan yang telah ditetapkan Allah.

Dari hasil observasi awal yang penulis temukan di SDIT Ihsanul Amal Alabio, adanya proses pembelajaran dan ruang belajar yang kurang kondusif, karena sistem pengajaran al-Qur'annya menggunakan kelompok dalam satu kelas yang terdiri dari kurang lebih 10-11 siswa dalam satu kelompok, sehingga ruang kelas yang ada tidak mencukupi. Terpaksa sebagian kelompok ada yang belajar di dalam masjid dan sebagian yang lain belajar di teras mesjid. Selain

${ }^{5}$ HM. Arifin, Kapita Selekta Pendidikan Nasional (Islam dan Umum), (Jakarta: CV. Bumi Aksara, 2000), hal. 72.

${ }^{6}$ Imam Al Ghazali, Terjemah Ihya' Ulumuddin Jilid I, (Semarang: CV. As Syifa', 1990), hal. 9.

Jurnal Ilmiah AL-MADRASAH, Vol. 2, No. 2, Januari-Juni 2018 
Ahmad Rifa'i: Implementasi Metode UMMI Untuk Meningkatkat Kualitas Membaca al-Quran di SDIT Ihsanul Amal Alabio

itu, sebagian siswa masih suka keluyuran ketika proses belajar mengajar, sehingga anak yang lain terganggu.$^{7}$

Padahal menurut Rosenshine dan Steven, salah satu konsep paling penting yang telah dikembangkan dalam psikologi pendidikan selama 30 tahun terakhir adalah bahwa variabel proses ruang kelas mempunyai hubungan yang paling langsung dengan prestasi siswa. ${ }^{8}$ Secara lebih spesifik, perilaku ruang kelas guru mempunyai pengaruh langsung terhadap perilaku siswa (yang paling penting adalah waktu pembelajaran akademis), yang pada gilirannya berkaitan secara langsung dengan ukuran prestasi siswa.

Selain faktor ruang belajar, juga faktor siswa yaitu tidak semua siswa memiliki kemampuan pemahaman baca al-Qur'an yang sama dan input siswa yang beragam, masih banyak siswa yang susah mengucapkan huruf "Ra' “ dikarenakan factor daerah, khususnya yang berasal dari daerah Amuntai merasa kesusahan dalam melafazkan huruf "Ra". Sedangkan dari faktor lainnya yaitu terbatasnya waktu dan kurangnya dorongan dari orang tua murid. ${ }^{9}$

Untuk mengatasi hal tersebut, perlu adanya upaya-upaya dari berbagai pihak. Salah satunya yang sangat penting adalah upaya dari guru al-Qur'an sendiri bagaimana cara mengajarkan al-Qur'an yang efektif sehingga anak dengan mudah memahami apa yang disampaikan guru. Untuk itulah bagaimana guru menentukan metode dan pendekatan yang tepat sehingga para siswa mampu meraih hasil belajar yang optimal dan mencapai target yang dicanangkan pihak kurikulum. ${ }^{10}$ Walaupun setiap metode pembelajaran di dalamnya terdapat kelebihan dan kekurangan, tapi bagi seorang guru kecermatan dalam memilih metode yang sesuai dengan situasi dan kondisi anak didik menjadi sangat penting. Misalnya ketika mengajarkan bacaan al-Qur'an,

${ }^{7}$ Observasi awal di SDIT Ihsanul Amal Alabio, tanggal 12 Januari 2014.

${ }^{8}$ Dina Indriana, Mengenal Ragam Gaya Pembelajaran Efektif, (Jogjakarta: DIVA Press, 2011), hlm. 62.

${ }^{9}$ Wawancara dengan Ustaz Muzakkir, guru al-Qur'an di SDIT hsanul Amal, tanggal 12 Januari 2014.

${ }^{10}$ Harun Maidir, dkk., Kemampuan Baca Tulis Al-Qur'an Siswa SMA, (Jakarta:DEPAG badan Litbang dan Puslitbang, 2007), hlm. 10.

Jurnal Ilmiah AL-MADRASAH, Vol. 2, No. 2, Januari-Juni 2018 
Ahmad Rifa'i: Implementasi Metode UMMI Untuk Meningkatkat Kualitas Membaca al-Quran di SDIT Ihsanul Amal Alabio

guru al-Qur'an hendaknya memilih metode yang memungkinkannya dapat memberi contoh sebanyak mungkin kepada anak didik, dan bukan hanya ceramah dengan menjelaskan beragam teori seputar ilmu tajwid.

Di dalam pembelajaran al-Qur'an, ada beberapa metode praktis belajar membaca al-Qur'an yang digunakan, diantaranya adalah metode Ummi. Metode Ummi inilah yang digunakan guru-guru di SDIT Ihsanul Amal Alabio. Metode ummi merupakan salah satu metode baca Qur'an yang terbaru. Metode ummi $^{11}$ diilhami oleh metode-metode pengajaran membaca al-Qur'an yang sudah tersebar di masyarakat, khususnya dari metode yang telah sukses mengantar banyak anak bisa membaca al-Qur'an dengan tartil, dan lain-lain

Alasan guru-guru memakai metode Ummi dikarenakan metode ini mempunyai variasi metode dalam mengajar.

Pendekatan yang digunakan dalam pembelajaran al-Qur'an dengan metode Ummi:

1) Privat / individual

2) Klasikal individual

3) Klasikal baca simak

4) Klasikal baca simak murni ${ }^{12}$

Pembelajaran membaca al-Qur'an di SDIT IHSANUL AMAL ALABIO, guru atau ustadz yang mengajar al-Qur'an telah di Tashih (dites) bacaannya terlebih dahulu. Pentashihan ini merupakan tahap awal bagi seseorang yang ingin mengajarkan al-Qur'an. Tashih bertujuan untuk mengetahui kompetensi ustadz atau ustadzah yang akan mengajar al-Qur'an. Guru al-Qur'an tersebut harus mengikuti pelatihan dan sertifikasi untuk mengetahui bagaimana cara mengajarkan membaca al-Qur'an kepada anak. Jadi guru- guru yang ada di SDIT IHSANUL AMAL ALABIO sudah mendapatkan

\footnotetext{
${ }^{11}$ Dikutip dari kata pengantar Tim Penyusun buku "Belajar Mudah Membaca Al-Qur'an Ummi”, (Surabaya: Lembaga Ummi Foundation, 2007).

${ }^{12}$ Ummi Foundation, ModulSertifikasi Guru Al-Qur'an Metode Ummi, (Surabaya: Lembaga Ummi Foundation, 2011), hlm. 9
}

Jurnal Ilmiah AL-MADRASAH, Vol. 2, No. 2, Januari-Juni 2018 
Ahmad Rifa'i: Implementasi Metode UMMI Untuk Meningkatkat Kualitas Membaca al-Quran di SDIT Ihsanul Amal Alabio

pelatihan dan sertifikasi tersebut dan telah mendapatkan rekomendasi dari pihak pusat. Di sinilah nantinya guru yang profesional berperan dalam mengatasi kesulitan atau kendala yang dialami siswa dalam belajar membaca al-Qur'an. Hal inilah yang mendorong penulis untuk mengadakan penelitian yang berjudul "Implementasi Metode Ummi Untuk Meningkatkan Kualitas Membaca AlQur'an di Sekolah Dasar Islam Terpadu Ihsanul Amal Alabio"

\section{B. Metode Penelitian}

Penelitian ini menggunakan metode deskriptif jenis penelitiannya studi kasus (case studies), penggunaan metode ini karena sebuah inguiry secara empiris yang menginvestigasi fenomena sementara dalam konteks kehidupan nyata (real life context), pendekatan ini dipergunakan ketika batas antara fenomena dan konteks tidak tampak secara jelas; dan sumber-sumber fakta ganda yang digunakan. Kasus yang diteliti adalah implementasi metode Ummi untuk meningkatkan kualitas membaca al-Quran di SDIT Ihsanul amal Alabio.

Sumber data berupa data primer dan data sekunder, sumber data primer yang dipilih dalam penelitian ini yaitu : narasumber (informan), peristiwa atau aktivitas, tempat atau lokasi. Sumber data sekunder yang menjadi rujukan peneliti dalam hal ini adalah semua dokumen SDIT Ihsanul Amal alabio, baik berupa dokumen tertulis seperti peraturan sekolah, jadwal pelajaran, buku panduan kurikulum, RPP, silabus, kalender akademik, serta dokumen yang berbentuk foto atau video dan data lain-lainnya. Teknik pengumpulan data dalam penelitian ini adalah menggunakan teknik observasi, wawancara, studi dokumentasi. Ketiga teknik ini digunakan diharapkan dapat memperoleh data dan informasi yang diperlukan dan dapat saling menunjang dan saling melengkapi. Sementara sebagai instrumen pengumpul data adalah peneliti sendiri (human intsrument) untuk memandu peneliti dalam pengumpulan data dan klasifikasi data, maka sebelumnya peneliti telah mempersiapkan kisi-kisi pengumpulan data. Analisis data dimulai dengan menelaah seluruh data yang dikumpulkan dari berbagai sumber, yaitu dari hasil pengamatan, wawancara, 
Ahmad Rifa'i: Implementasi Metode UMMI Untuk Meningkatkat Kualitas Membaca al-Quran di SDIT Ihsanul Amal Alabio

studi dokumen. Dalam menganalisis, peneliti melakukan interpretasi terhadap data-data yang berupa kata-kata, sehingga diperoleh makna (meaning). Karena itu analisis dilakukan bersama-sama dengan proses pengumpulan data, serta setelah data terkumpul. Data yang dikumpulkan direduksi, yakni menggolongkan, mengarahkan, membuang yang tidak perlu, dan mengorganisasi data. Kemudian setelah data-data direduksi, peneliti melakukan penyajian data, yakni menemukan pola-pola hubungan yang bermakna serta memberikan kemungkinan adanya penarikan kesimpulan data tersebut. Yang terakhir peneliti, menyimpulkan data-data dengan membuat makna tentang peristiwa-peristiwa yang terjadi.

\section{Hasil Penelitian}

Dari penelitian yang telah dilaksanakan oleh peneliti dengan judul "Implementasi Metode Ummi Untuk Meningkatkan Kualitas Membaca alQuran Di SDIT Ihsanul Amal Alabio”. Maka dari keterangan dalam teknik analisa data dalam penelitian ini, peneliti menggunakan analisis deskriptif kualitatif dan data yang diperoleh baik melalui observasi, interview, dokumentasi, dari pihak-pihak yang mengetahui tentang data yang peneliti butuhkan. Adapun data yang akan dipaparkan dan dianalisa oleh peneliti sesuai dengan rumusan penelitian di atas. Untuk lebih jelasnya peneliti akan membahasnya.

1. Implementasi Metode Ummi Dalam Upaya Meningkatkan Kualitas Membaca al-Quran di Sekolah Dasar Islam Terpadu (SDIT) Ihsanul Amal

Berdasarkan paparan data yang sebelumnya, dari hasil wawancara dengan kepala sekolah, guru al-Quran dan waka kurikulum di SDIT Ihsanul Amal Alabio peneliti dapat mengetahui sistem pembelajaran metode Ummi yang d terapkan di SDIT Ihsanul Amal Alabio sebagai berikut :

Kurikulum merupakan pengalaman yang diberikan lembaga 
Ahmad Rifa'i: Implementasi Metode UMMI Untuk Meningkatkat Kualitas Membaca al-Quran di SDIT Ihsanul Amal Alabio

pendidikan kepada peserta didik. Hal ini mencakup teknis yang diatur dalam lingkungan pendidikan, yang dinilai mendukung kelulusan peserta didik secara optimal. Kurikulum yang diterapkan di SDIT Ihsanul Amal Alabio ada 2 kurikulum yang dipakai. Pertama, kurikulum dari Dinas Pendidikan dan masih memakai KTSP. Dan dalam rencana kedepan akan memakai kurikulum 2013. Dan yang kedua, menggunakan kurikulum yang di keluarkan pihak Jaringan Sekolah Islam Terpadu (JSIT) yang dimana kurikulum ini juga mempunyai pandungan tersendiri. Panduan itupun terbagi lagi dalam beberapa buku tambahan. Dan yang paling utama dalam pembelajaran ke khas-an Sekolah Dasar Islam Terpadu adalah penambahan nilai-nilai ke Islaman, baik yang di ambil dari ayat-ayat suci al-Quran atau dari Hadist-hadist Nabi Muhammad Saw, atau cerita para sahabat, dan termasuk juga pengetahuan-pengetahuan yang berkaitan dengan dunia Islam. Begitu juga kurikulum dalam pembelajaran al-Quran yang dilaksanakan di SDIT Ihsanul Amal Alabio mengacu pada Ummi Foundation (sistem pembelajaran metode Ummi).

Materi pendidikan tidaklah mungkin terlaksana secara efektif dan efisien, jika seorang guru tidak menggunakan metode yang dapat membuat seorang siswa memahami atau mengerti apa yang disampaikan oleh seorang gurunya. Seorang guru haruslah memiliki metode efektif yang bisa memotivasi anak-anak untuk mencintai, membaca dan menjaga Al-Qur'an, sehingga dari kalangan pendidik tidak lagi mengeluh tentang anak-anak atau siswa yang tidak menyukai atau meremehkan kajian Al-Qur'an. ${ }^{13}$

Metode mengajar adalah cara guru mengajar. Metode mengajar adalah cara guru di dalam menyampaikan materi secara sistematis untuk mencapai tujuan pembelajaran yang telah dirumuskan. Dalam memilih metode pembelajaran yang perlu dipertimbangkan yaitu tujuan yang hendak dicapai, bahan atau materi pengajaran, kemampuan guru, dan

13 Muhammbad Fand Ats-Tsuwaini, 10 Metode Agar Anak Mencintai AlQur'an, terj., Dwi Ratnasari, (Yogyakarta: Al-Ajda Press, 2009), hlm. 18.

Jurnal Ilmiah AL-MADRASAH, Vol. 2, No. 2, Januari-Juni 2018 
Ahmad Rifa'i: Implementasi Metode UMMI Untuk Meningkatkat Kualitas Membaca al-Quran di SDIT Ihsanul Amal Alabio

kemampuan siswa, media sarana prasarana pengajaran yang tersedia, waktu yang dibutuhkan, dan keseluruhan situasi bagi berlangsungnya kegiatan belajar mengajar.

Kegiatan belajar dan mengajar di SDIT Ihsanul Amal Alabio mendapat dukungan sepenuhnya dari pihak yayasan SDIT Ihsanul Amal itu sendiri, kepala sekolah dan semua para guru. Tentunya dengan dukungan dari semua pihak ini para guru al-Quran dapat leluasa sepenuhnya untuk melakukan proses pembelajaran Ummi yang ada di SDIT Ihsanul amal. Dalam artian tidak lepas dari sistem pembelajaran dari Ummi Foundation.

Pembelajaran al-Qur'an di SDIT Ihsanul Amal ini beralokasi waktu 2x35 menit dalam setiap pertemuan. Dalam satu kelas ada beberapa kelompok, dan setiap kelompok mempunyai satu orang guru pengajar AlQur'an. Sedangkan tempat belajarnya ada yang di kelas, di mesjid dan di teras mesjid. Setiap kelas setiap harinya untuk pembelajaran al-Quran 2 jam pelajaran. 1 jam pelajaran beralokasi 35 menit, berarti 2 jam sama dengan 70 menit. Ditambah lagi dengan pemberian mata pelajaran alQuran 8 mata pelajaran per-minggu nya adalah sebuah perhatian khusus kepada mata pelajaran al-Quran khususnya dalam pembelajaran metode Ummi. Perhatian khusus ini dapat dilihat ketika pengaturan jam mata pelajaran maka jam pelajaran al-Quran yang berhubungan dengan metode Ummi ini yang dibuat lebih dahulu, setelah itu baru jam mata pelajaran lainnya. Semua ini bertujuan supaya anak-anak yang kelas rendah seperti anak-anak kelas 1,2 dan 3 mereka diberikan jam pelajaran metode Ummi di pagi hari agar mereka lebih fres. Untuk anak-anak kelas yang lebih tinggi mata pelajaran metode Ummi diletakkan di siang hari, karena mereka sudah besar dan bisa beradaptasi dengan pembelajaran Ummi.

Yang menjadi nilai lebih dari SDIT Ihsanul Amal, untuk pelajaran al-Quran dan tahfiz menjadi mata pelajaran unggulan dan lebih didahulukan dari mata pelajarn lainnya dan diberikan perhatian yang lebih. Selain menanamkan nilai-nilai al-Quran juga merupakan investasi masa 
Ahmad Rifa'i: Implementasi Metode UMMI Untuk Meningkatkat Kualitas Membaca al-Quran di SDIT Ihsanul Amal Alabio

depan untuk anak agar mereka tidak hanya cerdas duniawi tetapi juga agar cerdas ukhrawi.

Keterkaitan metode Ummi dalam meningkatkan kualitas membaca al-Quran di SDIT Ihsanul Amal Alabio membuat perubahan, kemajuan kualitas membaca al-Quran siswa dari berbagai aspek. Sebagaimana hasil wawancara kepada pihak yang terkait sebagai berikut

a. Guru

Sumber daya manusia memang diperlukan dalam hal ini. Mencari guru-guru al-Quran yang memang kompetin di bidang al-Quran sangat membantu dalam meningkatkan kualitas membaca al-Quran. Rata-rata guru/pengajar pelajaran al-Quran di rekrut dari lulusan Sekolah Tinggi Ilmu al-Quran (STIQ) yang sudah banyak hafalan dan bagus bacaannya serta bagus akhlaknya. Karena guru adalah teladan bagi siswa, apabila guru biasa menargetkan diri untuk selalu dekat dengan alQuran dan selalu membumikan al-Quran dalam hati dan pikiran mereka maka Insya Allah nantinya anak-anak bisa mengikuti jejak guru, karena guru itu panutan, kalau gurunya sudah begitu maka murid-murid nya akan ikut. Sekolah Tinggi Ilmu al-Quran (STIQ) adalah sebuah perkuliah yang tidak jauh dari SDIT Ihsanul Amal, dan guru-guru yang ada di sekolah tersebut kebanyakan dari lulusan Sekolah Tinggi Ilmu al-Quran (STIQ). Di STIQ mahasiswa diwajibkan menghafal al-Quran setiap semester 2 juz, dan minimal lulusan dari STIQ sudah punya hafalan 10 juz, bahkan sebagian sudah banyak yang menyelesaikan 30 juz hafalan al-Quran nya. Dengan kualitas guru seperti ini akan meningkatkan kualitas membaca al-Quran siswa-siswi di sekolah.

Selain pencarian SDM, kualitas guru juga perlu diperhatikan. Dan guru yang mengajar Al-Qur'an di sekolah ini sudah tersertifikasi dan mendapatkan pelatihan pengajaran Al-Qur'an yang cukup yang difasilitasi oleh pihak sekolah. Setelah mengajar maka akan terus dievaluasi bagaimana proses dia mengajar. Tujuannya adalah 
Ahmad Rifa'i: Implementasi Metode UMMI Untuk Meningkatkat Kualitas Membaca al-Quran di SDIT Ihsanul Amal Alabio

membangun sistem manajemen pengajaran Al Qur'an yang berbasis pada mutu, karena pembelajaran membaca Al Quran yang baik sangat membutuhkan sebuah sistem yang mampu menjamin mutu bahwa setiap anak usia lulus SD/MI harus bisa membaca Al-Qur'an secara tartil. Guru yang profesional pasti akan mempengaruhi kualitas pengajarannya. Sertifikasi dan pelatihan guru Ummi ini diselenggarakan resmi oleh Ummi Foundation dan yang diselenggarakan oleh LKPI, dan dilaksanakan di SDIT Ihsanul Amal. Tujuannya untuk meningkatkan kualitas guru tersebut supaya layak mengajar al-Quran di SDIT ini , dengan menggunakan metode Ummi. Kompetensi guru yang mengajar Ummi selalu di upgret dan di tingkatkan dengan pelatian-pelatihan, baik itu yang dilaksanakan oleh JSIT wilayah maupun oleh pihak SDIT Ihsanul Amal sendiri. Semua ini bertujuan agar guru-guru mempunyai variasi baru atau sebuah usaha kreatif dalam meningkatkan kualitas pembelajaran.

Berhubungan dengan pengajar, didukung lagi pihak kordinator mata pelajaran al-Quran disekolah ini selalu memantau dengan memberikan acuan semacam rumusan dan rambu-rambu ketika pembelajaran sesuai dengan Prosedur Ummi, dan cara mengemas pembelajaran tergantung kepada masing-masing guru di dalam pembelajaran agar terkordinasi dengan baik dalam menjaga kualitas membaca al-Quran. Disamping itu juga adanya dukungan dan kesepakatan oleh semua guru untuk menerapkan metode Ummi.

b. Pembelajaran Buku Ummi

Buku Ummi yang berkualitas menjadikan pula kualitas bacaan siswa meningkat dan ditambah warna buku Ummi yang berbeda-beda tiap jilidnya menjadikan daya tarik tersendiri bagi siswa. Dengan warna yang bervariasi mempengaruhi psikolog anak dalam mencintai pelajaran al-Quran.

Metode Ummi lebih sistematis, juga dari kontens isi jilid Ummi 
Ahmad Rifa'i: Implementasi Metode UMMI Untuk Meningkatkat Kualitas Membaca al-Quran di SDIT Ihsanul Amal Alabio

sendiri menyesuaikan dengan perkembangan psikolog anak, jadi lebih mudah menerapkannya karena sudah di sesuaikan dengan psikolog anak. Setiap jilid buku Ummi mempunyai pembahasan yang berbeda-beda, menyesuaikan tingkat kemampuan daya tangkap anak, dan inipun nantinya akan mempunyai pengaruh terhadap kualitas membaca alQuran. Karena penekanan dalam pembelajaran di jilid Ummi sangat diperhatikan seperti panjang-pendek dan lain sebagainya.

Dari sisi lagu Ummi juga sudah mempunyai lagu khusus pembelajaran metode Ummi dan mempunyai ciri khas tersendiri dan lagunya pun mudah dipelajari oleh anak. Lagu al-Quran ini membantu anak dalam meng-iramakan bacaan al-Quran, karena dengan lagu yang mendukung akan membuat siswa senang dan cepat dalam mempelajari al-Quran.

c. Pelajaran Pendukung

Jam khusus pun diberikan kepada siswa yang mengalami keterlambatan dalam belajar, atau kepada siswa yang lupa mengaji di rumah, dan kepada mereka yang belum mengulang hafalan al-Quran. Disediakan waktu khusus untuk mengulang hafalan dan sebagainya kepada sebagian ustaz/ustazah yang menangani mereka, dan di usahakan hafalan semua anak merata, sehingga ujian akhir sekolah kedepan misalkan hafalannya harus surah an-Naba semua anak di kelas memang harus sudah hafal surah tersebut. Waktu-waktu yang dimanfaatkan seperti waktu istirahat meminta waktu 5 menit atau sehabis shalat johor minta waktu 10 menit untuk anak tertentu untuk mengulang menyetorkan hafalannya al-Quran, agar tetap menjaga kualitas pembelajaran al-Quran.

Pelajaran lainnya yang mendukung pembelajaran Ummi yakni "tahfiz al-Quran", ketika anak sudah kelas empat mereka sudah menyelesaikan hafalan al-Quran juz 30/ juz Amma. Dan ketika mereka sudah kelas enam, hafalan yang mereka hafal 2 juz, yakni juz 30 dan 29. 
Ahmad Rifa'i: Implementasi Metode UMMI Untuk Meningkatkat Kualitas Membaca al-Quran di SDIT Ihsanul Amal Alabio

Selain tahfiz al-Quran, pelajaran pendukung lainnya yaitu hafalan hadist, hafalan do'a, shalat dhuha dan itu pelajaran wajib agar anak-anak terbiasa melakukan tilawah dan mengulang hafalan al-Quran sebelum belajar.

d. Evaluasi

Evaluasi dimaksudkan untuk memperoleh informasi sebagai dasar pembuatan keputuasan. Bentuk keputusan tersebut bisa berupa angka atau nilai setelah melalui pertimbangan tertentu. Tujuan evaluasi pembelajarn al-Quran bertujuan untuk meningkatkan kualitas pembelajaran al-Quran sekarang ataupun kedepannya.

Evaluasi dipandang sebagai kegiatan atau proses untuk mengukur dan selanjutnya menilai sejauhmana tujuan yang telah ditetapkan sudah dapat dilaksanakan. Kegiatan evaluasi selalu diawali dengan kegiatan pengukuran, yaitu proses penetapan angka menurut aturan tertentu, dilanjutkan penilaian, baru kemudian diakhiri dengan evaluasi. Penilaian dimaksudkan sebagai suatu kegiatan menafsirkan data hasil pengukuran. ${ }^{14}$ Guru al-Quran dalam pembelajaran metode Ummi di sekolah SDIT Ihsanul Amal melakukan evaluasi seperti evaluasi harian, dan nilai harian ini di totalkan di akhir bulan, juga dilakukan evaluasi tengah semester atau UTS, dan juga dilakukan ujian akhir semester, dan hasil semuanya adalah nilai raport. Kalau eveluasi mingguan dilakukan hanya untuk guru-guru yang mengajar metode Ummi. Dari evaluasi/rapat mingguan antar guru maka masukan dan problem yang di alami ketika mengajar di pecahkan bersama-sama guru yang lain, sehingga ada keinginan oleh pengajar untuk meningkatkan kualitas mengajar di bidang al-Quran.

14 Sudiyono, Anas. Pengantar Evaluasi Pendidikan. Jakarta : Raja Grafindo Persada. 1998 
Ahmad Rifa'i: Implementasi Metode UMMI Untuk Meningkatkat Kualitas Membaca al-Quran di SDIT Ihsanul Amal Alabio

2. Kualitas kemampuan Membaca al-Quran Setelah Diterapkan Metode Ummi di SDIT Ihsanul Amal Alabio

Setelah dilakukan observasi dan tes baca bacaan al-Quran kepada 8 orang siswa-siswa yang di ambil dari kelas 4, 5 dan 6, dengan materi tes dari ayat-ayat al-Quran, yaitu : al-Fatihah, al-Baqarah ayat 1-17, al-Quraisy ayat 1-5, al-An'am ayat 143, Fawatihussuwar (surah al-Qolam, Yasin, asSu'ara), al-Isra' ayat 55, al-Ikhlas ayat 1-4, al-Baqarah ayat 201, alMursalat ayat 20, al-Kafirun ayat 1-6, Yunus ayat 51. Dan melalui alat ukur tajwid yang meliputi : izhar, idghom bi ghunnah, idghom bilaghonnah, iqlab, ihfa hakiki, mim mati dan nun mati ghonnah, izhar syafawi, idghom misli, ihfa syafawi, idghom mutamatsilain, idghom mutajanisain, idghom mutaqoribain, lafaz Allah, qolqolah, izhar wajib, hokum ro', huruf syamsiyah, hukum qomoriyah, mad thobi'i, mad wajib, mad ja 'iz, mad 'arid lissukun, mad 'iwad, mad shillah, mad badal, mad tamkin, mad liin, mad lazim mutsaqqol kalimi, mad lazim mukhofaf kalimi, mad lazim mutsaqqol harfi, mad lazim mukhofaf harfi, mad farqi. Maka dapat disimpulkan melalui table di bawah ini :

\begin{tabular}{|l|l|c|c|}
\hline NO & \multicolumn{1}{|c|}{ NAMA } & SKOR TAJWID & KETERANGAN \\
\hline 1 & Habibah & 32 & Sangat Baik \\
3 & Siti Khodijah & 31 & Sangat Baik \\
4 & Rifqa Irhamna & 28 & Sangat Baik \\
5 & M. Yazid & 28 & Sangat Baik \\
6 & M. Fadhil & 32 & Sangat Baik \\
7 & As-Sudais & 32 & Sangat Baik \\
& & 32 & Sangat Baik \\
\hline
\end{tabular}

Jurnal Ilmiah AL-MADRASAH, Vol. 2, No. 2, Januari-Juni 2018 
Ahmad Rifa'i: Implementasi Metode UMMI Untuk Meningkatkat Kualitas Membaca al-Quran di SDIT Ihsanul Amal Alabio

\begin{tabular}{|l|l|c|c|}
\hline 8 & Nur Mahmudah & 32 & Sangat Baik \\
\hline
\end{tabular}

\section{Keterangan :}

25-32 : Sangat Baik ${ }^{15}$

17-24 : Baik

9-16 : Cukup

1-8 : Kurang

Dari data di atas siswa SDIT Ihsanul Amal dapat dikatagorikan sebagai :

\begin{tabular}{|l|l|c|c|}
\hline NO & JUMLAH SISWA & NILAI & KETERANGAN \\
\hline 1 & 5 Orang & 32 & Sangat Baik \\
2 & 2 Orang & 28 & Sangat Baik \\
3 & 1 Orang & 31 & Sangat Baik \\
\hline
\end{tabular}

Jadi kualitas bacaan al-Quran setelah diterapkan metode Ummi di SDIT Ihsanul Amal Alabio Sangat Baik. Hanya sebagian kecil yang perlu diperbaiki kualitas bacaannya.

\section{Simpulan}

Dari penelitian yang dilakukan peneliti dengan judul "Implementasi Metode Ummi Untuk Meningkatkan Kualitas Membaca al-Quran Di SDIT Ihsanul Amal Alabio". Berdasarkan data yang diperoleh dari observasi, wawancara serta dokumentasi dapat disimpulkan sebagai berikut:

Implementasi metode Ummi untuk meningkatkan kualitas membaca alQuran di SDIT Ihsanul Amal Alabio yaitu: kurikulum yang diterapkan 2

15 Ummi Foundation, Modul Sertifikasi Guru al-Quran Metode Ummi (Surabaya : Lembaga Ummi Foundation, 2011), hal 31

Jurnal Ilmiah AL-MADRASAH, Vol. 2, No. 2, Januari-Juni 2018 
Ahmad Rifa'i: Implementasi Metode UMMI Untuk Meningkatkat Kualitas Membaca al-Quran di SDIT Ihsanul Amal Alabio

kurikulum (kurikulum KTSP dan kurikulum dari Jaringan Sekolah Islam Terpadu (JSIT). Penerapan pembelajaran metode Ummi mendapat antusias yang tinggi dari pihak lembaga SDIT Ihsanul Amal, kepala sekolah dan pihak guru. Pembelajaran al-Qur'an di SDIT Ihsanul Amal ini beralokasi waktu 2x35 menit dalam setiap pertemuan dan $8 \mathrm{JP} /$ minggu. Guru yang mengajar metode Ummi sudah mendapatkan sertifikat dari Ummi Foundation. SDM yang berkualitas karena guru al-Quran dari lulusan Sekolah Tinggi Ilmu al-Quran (STIQ). Kordinator pembelajaran Ummi di sekolah ini selalu memantau dengan memberikan acuan semacam rumusan dan rambu-rambu ketika pembelajaran sesuai dengan Prosedur Ummi. Buku Ummi yang berkualitas menjadikan pula kualitas bacaan siswa meningkat, desain warna yang berbeda tiap jilid membuat anak-anak semangat dalam pembelajaran, dan setiap jilid mempunyai pembahasan yang berbeda-beda, menyesuaikan kemampuan daya tangkap anak. Ditambah juga metode Ummi mempunyai lagu khas tersendiri. Pelajaran yang mendukung metode Ummi seperti hafalan al-Quran, anak-anak kelas empat sudah hafal juz 30 dan kelas enam sudah hafal 2 juz yang meliputi juz 30 dan 29. Hafalan hadist, hafalan do'a dan tadarus sebelum belajar sangat mendukung pembelajarn al-Quran khususnya metode Ummi. Pelaksanaan evaluasi pembelajarn al-Quran bertujuan untuk meningkatkan kualitas pembelajaran seperti evaluasi harian, dan nilai harian di totalkan di akhir bulan, juga dilakukan evaluasi tengah semester atau UTS, dan juga dilakukan ujian akhir semester. Evaluasi dari pihak guru juga dilakukan guna meningkatkan kualitas pembelajaran al-Quran.

Kualitas membaca al-Quran setelah diterapkan metode Ummi di SDIT Ihsanul Amal Alabio yaitu: siswa lebih tepat dalam mengenal bacaan al-Quran sesuai dengan kaidah tajwid yang berlaku.

Hasil dari penelitian dapat disimpulkan melalui table di bawah ini hasil:

Jurnal Ilmiah AL-MADRASAH, Vol. 2, No. 2, Januari-Juni 2018 
Ahmad Rifa'i: Implementasi Metode UMMI Untuk Meningkatkat Kualitas Membaca al-Quran di SDIT Ihsanul Amal Alabio

\begin{tabular}{|l|l|c|c|}
\hline NO & \multicolumn{1}{|c|}{ NAMA } & SKOR TAJWID & KETERANGAN \\
\hline 1 & Habibah & 32 & Sangat Baik \\
3 & Siti Khodijah & 31 & Sangat Baik \\
4 & Muhammad Hendra & 28 & Sangat Baik \\
5 & M. Yazid & 28 & Sangat Baik \\
6 & M. Fadhil & 32 & Sangat Baik \\
7 & As-Sudais & 32 & Sangat Baik \\
8 & Nur Mahmudah & 32 & Sangat Baik \\
\hline
\end{tabular}

Dari data di atas siswa SDIT Ihsanul Amal dapat dikatagorikan sebagai

\begin{tabular}{|l|l|c|c|}
\hline NO & JUMLAH SISWA & NILAI & KETERANGAN \\
\hline 1 & 5 Orang & 32 & Sangat Baik \\
2 & 2 Orang & 28 & Sangat Baik \\
3 & 1 Orang & 31 & Sangat Baik \\
\hline
\end{tabular}

Jurnal Ilmiah AL-MADRASAH, Vol. 2, No. 2, Januari-Juni 2018 
Ahmad Rifa'i: Implementasi Metode UMMI Untuk Meningkatkat Kualitas Membaca al-Quran di SDIT Ihsanul Amal Alabio

\section{Daftar Pustaka}

As-Syilasyabi , Abu Yahya. Cara Mudah Membaca Al-Qur'an Sesuai Kaidah Tajwid. Yogyakarta: Daar Ibn Hazm, 2007

Arifin, HM. kapita Selekta Pendidikan Nasional (Islam dan Umum). Jakarta: CV. Bumi Aksara, 2000

Al Ghazali , Imam. Terjemah Ihya' Ulumuddin Jilid I. Semarang : CV. As Syifa', 1990

Anas ,Sudiyono. Pengantar Evaluasi Pendidikan. Jakarta : Raja Grafindo Persada.1998

Foundation , Ummi. Modul Sertifikasi Guru Al-Qur'an Metode Ummi. Surabaya: Lembaga Ummi Foundation, 2011

Indriana, Dina . Mengenal Ragam Gaya Pembelajaran Efektif. Jogjakarta: DIVA Press, 2011

Muda Harahap, Hakim. Rahasia Al-Quran. Depok : Darul Hikmah, 2007

Muhammad Ibnu Ismail, Imam Abu Abdillahi. Kitab Shahih Bukhori. Beirut, Lebanon: Darul Kutub Al Ilmiyah, 1992

Munjin Nasih , Ahmad dan Nur Kholidah, Lilik. Metode dan Teknik Pembelajaran Pendidikan Agama Islam. Bandung: Refika Aditama, 2009

Maidir , Harun, dkk. Kemampuan Baca Tulis Al-Qur'an Siswa SMA. Jakarta:DEPAG badan Litbang dan Puslitbang, 2007

Masruri “Belajar Mudah Membaca Al-Qur'an Ummi”. Surabaya: Lembaga Ummi Foundation, 2007

Muhammbad, Fand Ats-Tsuwaini. 10 Metode Agar Anak Mencintai Al-Qur'an, terj., Dwi Ratnasari. Yogyakarta: Al-Ajda Press, 2009

RI Depag. Metode-metode Membaca Al-Qur'an di Sekolah Umum. Jakarta: Dirjen Pembinaan Kelembagaan Agama Islam, 1997

Undang-undang Republik Indonesia No. 22 Tahun 2003 tentang Sistem Pendidiakan Nasional, BAB II pasal 3 tentang Dasar, fungsi dan tujuan.

Jurnal Ilmiah AL-MADRASAH, Vol. 2, No. 2, Januari-Juni 2018 
Ahmad Rifa'i: Implementasi Metode UMMI Untuk Meningkatkat Kualitas Membaca al-Quran di SDIT Ihsanul Amal Alabio

Jurnal Ilmiah AL-MADRASAH, Vol. 2, No. 2, Januari-Juni 2018 